\title{
MONITORING OF GENETICALLY MODIFIED FOOD ON THE CZECH FOOD MARKET AND A CROSS-COUNTRY COMPARISON
}

\author{
V. Kyrova*, V. Ostry, P. Surmanova and J. Ruprich \\ Center for Health, Nutrition and Food, National Institute of Public Health in Prague, \\ Palackeho 3a, 61242 Brno. Czech Republic
}

(Received: 1 December 2016; accepted: 28 March 2017)

\begin{abstract}
The presence of genetically modified organisms (GMOs) was analysed in food samples from the Czech food markets. Four different types of food samples (soya beans, soya bean products, maize flour, and rice) were collected at twelve places in four terms in the years 2008-2013. It represents a total 1152 food samples. Soya and maize were chosen, because these are the major transgenic crops grown worldwide. Increased cultivation of GM rice in China, India, Indonesia, and the Philippines has been observed. Polymerase chain reaction-based methods were applied to detect GMOs. GMOs were detected in 107 samples (9.3\%). The results show that in food from the Czech food market GMOs mainly in maize flour and rice were found. GM maize was detected in $63(21.9 \%)$ maize flour samples. Maize lines MON810, NK603, and Bt176 were detected in $14(22 \%), 9(14 \%)$, and 1 (1.6\%) maize flour samples, respectively. Unauthorised GM rice was detected in $39(13.5 \%)$ rice samples. Unauthorised rice Bt63 was detected in one sample of rice. Roundup Ready soya was detected in $4(1.4 \%)$ soya bean samples and in $1(0.35 \%)$ soya product sample. These results were compared with results of the world's studies.

Keywords: GMOs, foodstuffs, monitoring, PCR
\end{abstract}

Genetic engineering and genetic modification are terms that relate to the manipulation of an organism's genes through recombinant DNA technology. Genetically modified (GM) crops have been modified through the introduction of new agronomic traits or suppression of constituent genes, which code for e.g. disease/pest resistance, herbicide tolerance, increase of nutritional value (QAIM, 2009; RoNALD, 2011).

GM crops have set a precedent in that the biotech area has grown impressively every single year for the past 19 years, with a remarkable 100-fold increase since the commercialization began in 1996. Thus, GM crops are considered as the fastest adopted crop technology in the history of modern agriculture. A total of 18 million farmers planted biotech crops in 28 countries, wherein over $94.1 \%$ were small and resource-poor farmers from developing countries. Of the 28 countries planting biotech crops in 2014, 19 countries planted 50000 hectares or more GM crops. These mega-countries include' e.g. the USA, Brazil, Argentina, India, Canada, China, Mexico, and Spain. To provide a global perspective of the status of GM crops, the global adoption rates as a percentage of the respective global areas of the four principal crops are - soya bean $(82 \%)$, cotton $(68 \%)$, maize $(30 \%)$, and canola $(25 \%)$ (JAMES, 2014).

\footnotetext{
* To whom correspondence should be addressed.

Phone: +4205015577525; fax: +420541212953; e-mail: kyrova@chpr.szu.cz
}

This is an open-access article distributed under the terms of the Creative Commons Attribution 4.0 License, which permits unrestricted use, distribution, and reproduction in any medium for non-commercial purposes, provided the original author and source are credited. 
GM crops are involved in the production of a variety of GM food. The release and consumption of GM food can raise questions about health and environmental safety. Available impact studies of insect-resistant and herbicide-tolerant crops show that these technologies are beneficial to farmers and consumers, as well as have positive effects on the environment and human health. GM crops can contribute significantly to global food security and poverty reduction. Nonetheless, widespread public reservations have led to a complex system of regulations. Overregulation has become a real threat for the further development and use of GM crops. The costs in terms of foregone benefits may be large, especially for developing countries. Economics research has an important role to play in designing efficient regulatory mechanisms and agricultural innovation systems (QAIM, 2009; RAVEN, 2014).

The use of GMOs raises several ethical issues. There are increased consumer concerns over the use of GMOs in food products, mainly in the European Union (EU) countries, while in North America, the technology is more accepted. In order to guarantee consumers' freedom of choice, the use of GMOs and GMOs derived products in the food chain is subject to precise regulations in several countries. The labelling of food and a derived product is mandatory in the EU with a threshold of $0.9 \%$ (KYrovA et al., 2010). The above-mentioned facts clearly demonstrate the need for an official control of food products by the Czech regulatory and inspection authorities (e.g. Czech Agriculture and Food Inspection Authority).

The objective of this study was to determine qualitatively the occurrence of products derived from genetically modified soya, maize, and rice in foods sold commercially in the Czech Republic. Soya and maize were chosen, because these are the major transgenic crops grown world-wide. Increased cultivation of GM rice in China, India, Indonesia, and the Philippines has been observed (GMO Compass, 2015). The study was realised by project of the Monitoring the environmental impact on population health of the Czech Republic, subsystem 4: Health effects and risks of human dietary exposure to contaminants. The occurrence data of unauthorised and authorised GMO in foodstuffs are very important and serve as a basis for public health protection and promotion.

\section{Materials and methods}

\subsection{Collection and sampling procedures}

Four types of food samples: soya beans, soya products (soya bean meal, dehydrated textured soya bean protein), maize flour (fine, medium-coarse, coarse), and rice (long grain rice, medium grain rice, short grain rice, basmati rice) were collected in four sampling terms in 12 regions of the Czech Republic in years 2008-2013. A total of 1152 food samples were gathered. None of these samples were labelled as containing or consisting of GMOs.

\subsection{DNA extraction}

The samples were ground in an electric mill. DNA was extracted from the sample $(50 \mathrm{mg})$ using commercial kit PowerPlant ${ }^{\mathbb{P}}$ Pro DNA Isolation Kit (MoBio laboratories, Carlsbad, USA) according to the producer's recommendation. DNA from reference materials was extracted from $50 \mathrm{mg}$ material using the same method. The DNA quantity and purity were estimated by measuring the absorbance at $260 \mathrm{~nm}$ and at $280 \mathrm{~nm}$ by means of a Helios Gamma spectrophotometer (Thermo Spectronic, Cambridge, UK). 


\subsection{Qualitative $P C R$}

Amplifications were carried out with a final volume of $25 \mu \mathrm{l}$ of reaction mix by means of a GeneAmp PCR System 2400 (Applied Biosystems, Foster City, USA). All used primer sequences are listed in Table 1. Oligonucleotides were synthesized by IDT (USA). The PCR products were verified on $2 \%$ agarose gel electrophoresis and visualized under UV illumination in a Vilber Lourmat Documentation System and analysed by Bio-Capt MW (Vilber Lourmat, Marne La Vallée, France). Amplifiability of DNA samples were confirmed using plant specific primers from soya (lectin gene), maize (invertase gene) and rice (chloroplast gene). Screening (CaMV 35S promotor, NOS terminator), construct specific (RoundupReady soya bean (RRS), maize Bt11, Bt176, T25, GA21, StarLink, DAS1507, NK603, rice Bt63, MIR604, Bt10), and event specific (maize MON810) methods for GMO detection in foods are given in Table 1.

Table 1. List of primers and methods used for GMO screening and identification tests

\begin{tabular}{|c|c|c|c|c|}
\hline Target & Primer & Sequence ( $5^{\prime}$ to $\left.3^{\prime}\right)$ & $\begin{array}{l}\text { Amplicon } \\
\text { size (bp) }\end{array}$ & Reference \\
\hline $\begin{array}{l}\text { Soya (Glycine } \\
\max )\end{array}$ & $\begin{array}{l}\text { GMO03 } \\
\text { GMO04 }\end{array}$ & $\begin{array}{l}\text { GCCСТCTACTCCACCCCCATCC } \\
\text { GCCCATCTGCAAGCCTTTTTGTG }\end{array}$ & 118 & $\begin{array}{l}\text { CSN EN ISO } \\
21569,2005\end{array}$ \\
\hline $\begin{array}{l}\text { Maize }(Z e a \\
\text { mays })\end{array}$ & $\begin{array}{l}\text { IVR1-F } \\
\text { IVR1-R }\end{array}$ & $\begin{array}{l}\text { CCGCTGTATCACAAGGGCTGGTAC C } \\
\text { GGAGCCCGTGTAGAGCATGACGATC }\end{array}$ & 226 & $\begin{array}{l}\text { CSN EN ISO } \\
21569,2005\end{array}$ \\
\hline $\begin{array}{l}\text { Chloroplast } \\
\text { gene (trnL) }\end{array}$ & $\begin{array}{l}\text { A1 } \\
\text { A2 }\end{array}$ & $\begin{array}{l}\text { CGAAATCGGTAGACGCTACG } \\
\text { GGGGATAGAGGGACTTGAAC }\end{array}$ & 614 & $\begin{array}{l}\text { CSN EN ISO } \\
21569,2005\end{array}$ \\
\hline P35S & $\begin{array}{l}35 \mathrm{~S}-\mathrm{cf} 3 \\
35 \mathrm{~S}-\mathrm{cr} 4\end{array}$ & $\begin{array}{l}\text { CCACGTCTTCAAAGCAAGTGG } \\
\text { TCСТCTCCAAATGAAATGAACTTCC }\end{array}$ & 123 & $\begin{array}{l}\text { CSN EN ISO } \\
21569,2005\end{array}$ \\
\hline tNOS & $\begin{array}{l}\text { HA-nos } 118 \mathrm{f} \\
\text { HA-nos118r }\end{array}$ & $\begin{array}{l}\text { GCATGACGTTATTTATGAGATGGG } \\
\text { GACACCGCGCGCGATAATTTATCC }\end{array}$ & 118 & $\begin{array}{l}\text { CSN EN ISO } \\
21569,2005\end{array}$ \\
\hline RRS & $\begin{array}{l}\text { 35S-f2 } \\
\text { Petu-r1 }\end{array}$ & $\begin{array}{l}\text { TGATGTGATATCTCCACTGACG } \\
\text { TGTATCCCTTGAGCCATGTTGT }\end{array}$ & 172 & $\begin{array}{l}\text { CSN EN ISO } \\
21569,2005\end{array}$ \\
\hline Bt11 & $\begin{array}{l}\text { IVS2-2 } \\
\text { PAT-B }\end{array}$ & $\begin{array}{l}\text { CTGGGAGGCCAAGGTATCTAAT } \\
\text { GCTGCTGTAGCTGGCCTAATCT }\end{array}$ & 189 & $\begin{array}{l}\text { CSN EN ISO } \\
21569,2005\end{array}$ \\
\hline Bt176 & $\begin{array}{l}\text { Cry03 } \\
\text { Cry04 }\end{array}$ & $\begin{array}{l}\text { CTCTCGCCGTTCATGTCCGT } \\
\text { GGTCAGGCTCAGGCTGATGT }\end{array}$ & 211 & $\begin{array}{l}\text { CSN EN ISO } \\
21569,2005\end{array}$ \\
\hline $\mathrm{T} 25$ & $\begin{array}{l}\text { T25-F7 } \\
\text { T25-R3 }\end{array}$ & $\begin{array}{l}\text { ATGGTGGATGGCATGATGTTG } \\
\text { TGAGCGAAACCCTATAAGAACCC }\end{array}$ & 209 & $\begin{array}{l}\text { CSN EN ISO } \\
21569,2005\end{array}$ \\
\hline MON810 & $\begin{array}{l}\text { VW01 } \\
\text { VW03 }\end{array}$ & $\begin{array}{l}\text { TCGAAGGACGAAGGACTCTAACG } \\
\text { TCCATCTTTGGGACCACTGTCG }\end{array}$ & 170 & $\begin{array}{l}\text { CSN EN ISO } \\
21569,2005\end{array}$ \\
\hline NK603 & $\begin{array}{l}\text { NK603F } \\
\text { NK603R }\end{array}$ & $\begin{array}{l}\text { TTTGTTTTATTTTGGACTATCCCGACTC } \\
\text { CAAGAAGGGGAGGAGGTAAACAGAT }\end{array}$ & 305 & $\begin{array}{l}\text { BEHR et al., } \\
2017\end{array}$ \\
\hline Bt10 & $\begin{array}{l}\text { JSF5 } \\
\text { JSR5 }\end{array}$ & $\begin{array}{l}\text { CACACAGGAGATTATTATAGGGTTACTCA } \\
\text { ACACGGAAATGTTGAATACTCATACTCT }\end{array}$ & 117 & $\begin{array}{l}\text { MAZZARA et } \\
\text { al., } 2005\end{array}$ \\
\hline GA21 & $\begin{array}{ll}\text { GA21 } & 1-5 \\
\text { GA21 } & 1-3\end{array}$ & $\begin{array}{l}\text { ACGGTGGAAGAGTTCAATGTATG } \\
\text { TCTCCTTGATGGGCTGCA }\end{array}$ & 270 & $\begin{array}{l}\text { CHIUEH et al., } \\
2002\end{array}$ \\
\hline StarLink & $\begin{array}{l}\text { CM03 } \\
\text { CBH02 }\end{array}$ & $\begin{array}{l}\text { CCTTCGCAAGACCCTTCCTCTATA } \\
\text { GTAGCTGTCGGTGTAGTCCTCGT }\end{array}$ & 170 & $\begin{array}{l}\text { CHIUEH et al., } \\
2002\end{array}$ \\
\hline MIR604 & $\begin{array}{l}\text { MIR604-mF } \\
\text { DAS-59122-7-rb1R }\end{array}$ & $\begin{array}{l}\text { GTGAATGGAGATGGACGGATGC } \\
\text { CCTTAATTCTCCGCTCATGATCAG }\end{array}$ & 201 & $\begin{array}{l}\text { OGUCHI et al., } \\
2008\end{array}$ \\
\hline Bt63 & $\begin{array}{l}\text { T51F } \\
\text { T51R }\end{array}$ & $\begin{array}{l}\text { GACTGCTGGAGTGATTATCGACAGA } \\
\text { AGCTCGGTACCTCGACTTATTCAG }\end{array}$ & 83 & $\begin{array}{l}\text { MÄDE et al., } \\
2006\end{array}$ \\
\hline
\end{tabular}

Acta Alimentaria 47, 2018 
Validated and accredited PCR method was employed for GM food detection (CSN EN ISO/IEC 17025, 2005; KYrova et al., 2010). Limit of detection of the methods (LOD) were $0.1 \%$.

Certified reference materials (CRM) from the Institute for Reference Materials and Measurements (IRMM, Geel, Belgium) were acquired from Fluka (Buchs, Switzerland) and used for validation of the method for the detection of RRS (IRMM 410) and maize events Bt11 (IRMM 412), MON810 (IRMM 413), Bt176 (IRMM 411). For maize T25, GA21, StarLink, DAS1507, and rice Bt63 the genomic DNA from GeneScan Europe (Freiburg, Germany) was used. As positive control for maize Bt10, maize flour from EURL (European Reference Laboratory for GM Food and Feed, Ispra, Italy) was used.

\section{Results and discussion}

An occurrence of GM soya, GM maize, and GM rice in foods is presented in Table 2. Figure shows the number of positive samples in different years. In total, GMOs were detected in 107 food samples $(9.3 \%)$. The results show that GMOs were found rather in maize flour and rice than in soya bean and soya products in foods from the Czech food market. GM maize was detected in 63 (21.9\%) maize flour samples. Maize lines MON810, NK603, and Bt176 were detected in $14(22 \%), 9(14 \%)$, and $1(1.6 \%)$ maize flour samples, respectively. Unauthorised GM rice was detected in $39(13.5 \%)$ rice samples. Unauthorised rice Bt63 was detected in one sample of rice. Further not specified genetic modifications were found in 39 positive samples of maize flour and 38 positive samples of rice by using identification PCR method. RRS was detected in $4(1.4 \%)$ soya bean samples and in $1(0.35 \%)$ soya product sample.

Table 2. Occurrence of GMOs in foods in 2008-2013

\begin{tabular}{lccc}
\hline Foodstuffs & $\mathrm{n}$ & $\mathrm{n}+$ & $\% \mathrm{n}+$ \\
\hline Soybean & 288 & 4 & 1.4 \\
Soya products & 288 & 1 & 0.35 \\
Maize flour & 288 & 63 & 21.9 \\
Rice & 288 & 39 & 13.5 \\
Total & 1152 & 107 & 9.3 \\
\hline
\end{tabular}

$\mathrm{n}$ : number of samples; $\mathrm{n}+$ : number of positive samples; $\% \mathrm{n}+$ : percent of positive samples

In our previous study, soya beans, soya products, maize flour, and rice were collected in the Czech Republic during the years 2002-2007. RRS was detected in 14 (4.9\%) samples of soya bean out of 288 and in $88(30.5 \%)$ soya products out of 288 samples. GM maize was detected in $5(1.7 \%)$ of 288 samples. Maize lines MON810, Bt176, and StarLink were detected in the maize samples. GM rice was detected in $2(1.9 \%)$ samples out of 102 (KYROVA et al., 2010).

Our results were compared with the results from recent studies in Europe and in the world.

Several countries have conducted survey to monitor the presence of GMOs in foods. For example, 251 soya food samples were bought from the Hungarian food market. According to the results, $38 \%$ of the examined samples indicated presence of RRS in soya-containing foods (UJHELYI et al., 2008). 


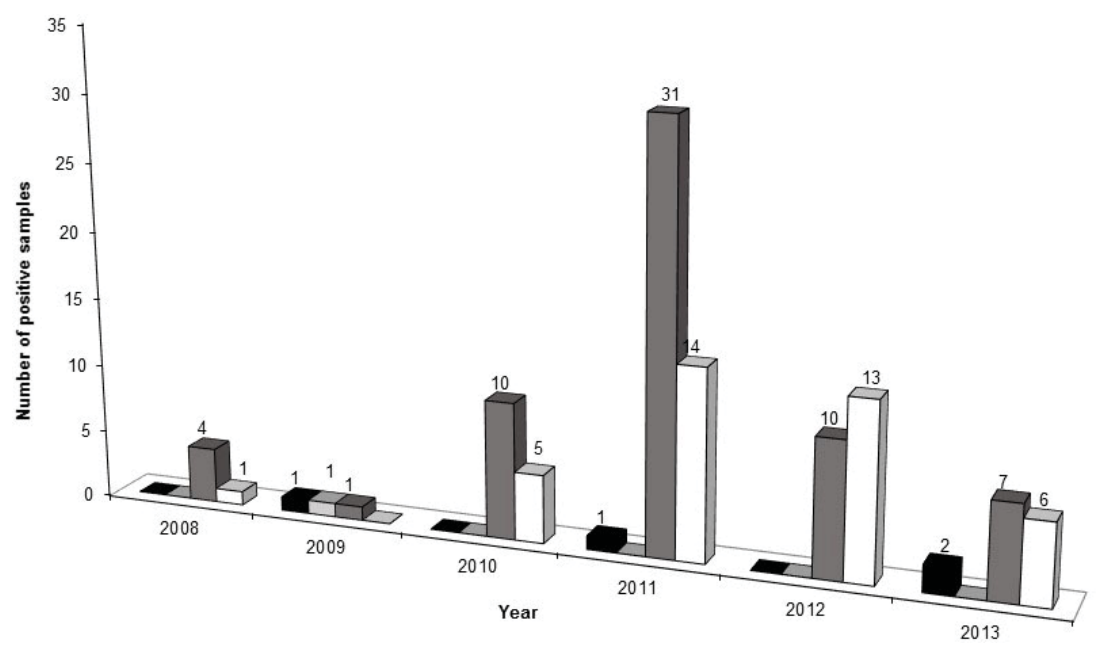

Fig. 1. GMO positive samples in years 2008-2013

: Soya bean; $\square$ : Soya products; $\square$ : Maize flour; $\square$ Rice

Food testing for the presence of GMOs was also realised in Croatia. Among the most common analysed food samples were soya bean and maize as well as their products. During 2004-2007 2797 samples were analysed and 139 (4.97\%) contained GMO. The most positive results were found in samples like spice mixtures and other raw materials (based on soya bean) for further processing in the food industry (meat, bakery industry) originating from import (CATTUNAR et al., 2011).

Two types of maize flour and four types of soya products were qualitatively analysed during 2013 in Romania. The presence of GMO both in a maize sample and a soya sample was found (CURTICĂPEAN \& CURTICĂPEAN, 2014).

A total of 119 food maize samples were acquired in Portugal local supermarkets. The overall results of GMO screening were $30 \%$ for $35 \mathrm{~S}$ promoter, $10 \%$ for NOS terminator, and $25 \%$ for identified events. The most frequently detected events were MON810, TC1507, and NK603, with one sample containing GA21 (FERNANDES et al., 2014).

In a Serbian study, the presence of genetic modifications was analysed in a total of 100 samples of non-labelled vegetarian and healthy food products. The basic raw materials in the tested samples were maize, soya, and/or rice. The $35 \mathrm{~S}$ promoter was detected in $8(8 \%)$ samples. None of the analysed samples contained GM maize and GM rice (ZDJELAR et al., 2013).

GM maize and GM soya in processed food products and feed were found in Turkish studies. Current legislation has restricted the penetration of GM maize into the Turkish food industry but not eliminated it, and the proliferation of different GM events is making monitoring increasingly complex. These results indicate that labelling requirements are not being followed in some cases (OzGen Arun et al., 2013; TuRKEC et al., 2016).

Two hundred samples of GM foods were collected and analysed in 2009 and 2010 in the Kingdom of Saudi Arabia (ELSANHOTY et al., 2013). The results indicated that all rice samples 
gave negative results. About $26 \%$ of samples containing soya bean and $44 \%$ of samples containing maize were positive for $35 \mathrm{~S}$ promoter and NOS terminator. Using event-specific method, maize lines Bt176 (20.4\%), Bt11 (8.8\%), T25 (8.8\%), MON810 (5.9\%), and StarLink $(5.9 \%)$ were found.

In a Jordanian study it was investigated at what level Jordanian consumers are exposed to GM foods. DNA was extracted from 200 food and 80 feed samples bought in Jordanian markets and investigated by PCR. Fifteen (5.4\%) food and feed samples were found positive for maize Bt176 or RRS genes. The GM elements were detected in more than $62.5 \%$ with less than $1 \%$ modification, compared to less than $37.5 \%$ containing more than $1 \%$ GM (HERZALLAH, 2012).

There are no legislations on GM labelling and cultivation of GM crops in Tunisia. The present study aims to check the status of GMO on the Tunisian market. Three hundred and sixty-five samples were collected. Seven food and feed products showed signs of RRS $(1.9 \%)$, MON810 (2.1\%), and Bt11 (1.6\%). The results demonstrate for the first time the presence of GMO in Tunisian markets (CHAOUACHI et al., 2013).

In opposition to these findings, Brazilian authors did not detect transgenic maize in commercialised foods from Brazil along the years of 2002-2007 (BRANQUINHO et al., 2010; Dinon et al., 2010). Branquinho and co-workers (2010) analysed 240 samples of soyaderived foodstuffs from 2004 to 2007. In food containing soya bean, 68 (28.3\%) were shown to contain GM soya bean.

Seventy-four processed maize-containing foods from the USA, China, Japan, and South Korea were analysed. Results showed that 18 (24\%) out of 74 samples contained one or more GM maize product. From the 24 samples obtained from South Korean markets, 4 (17\%) contained GM maize. Two samples out of 20 from Japan contained detectable levels of GM maize events. More than $50 \%$ of the examined 20 food samples from the US food markets contained detectable GM maize events. Neither GM maize events in the 10 samples from the Chinese markets were found. Among the detectable GM events, NK603 and TC1507 were observed in $14(78 \%)$ of the 18 positive GM maize samples, DAS-59122-7 in $13(72 \%)$, MON810 and MON863 in $11(61 \%)$, MON88017 in $6(33 \%)$, Bt11 in $4(22 \%)$, GA21 in 3 (17\%), T25, MIR604, and LY038 in 2 (11\%), and Bt176 in one (5.5\%) sample (KIM et al., 2014).

\section{Conclusions}

Foodstuffs on the Czech and world market contained authorised and unauthorised GMOs. Consumers have the possibility to choose between GM or non-GM foodstuffs. They expect food to be safe and healthy. There is no information about adverse effect on human health of authorised GM foodstuffs. The further study of monitoring should mainly be focused on detection and identification of unauthorised GMOs, e.g. rice and papaya.

Supported by Ministry of Health, Czech Republic - conceptual development of research organization ("National Institute of Public Health - NIPH, IN 75010330").

\section{References}

Behr, C.F., Hironaka, C., Heck, G.R. \& You, J. (2017): Corn transformant PV-ZMGT32 (NK603) and compositions and methods for detection thereof. Available from: http://www.ncbi.nlm.nih.gov/nuccore/18151812. (Last accessed March 3, 2017). 
Branquinho, M.R., Ferreira, R.T.B. \& Cardarelli-Leite, P. (2010): Survey of compliance with labelling legislation in food containing GMOs in Brazil. J. Food Comp. Anal., 23, 220-225.

Cattunar, A., Capak, K., Novak, J.Z., Mićović, V., Doko-Jelinić, J. \& Malatestinić, D. (2011): Monitoring the presence of genetically modified food on the market of the Republic of Croatia. Coll. Antropol., 35, 12311236.

CurticăPean, M. \& CurticăPEAn, A. (2014): Detection of the genetically modified organisms from food products. Rom. J. Lab. Med., 22, 387-396.

Chaouachi, M., Nabi, N., Hafsa, A.B., Zellama, M.S., Skhiri, F. \& Saïd, K. (2013): Monitoring of genetically modified food and feed in the Tunisian market using qualitative and quantitative real-time PCR. Food Sci. Biotechnol., 22, 1161-1170.

Chiuen, L.C., Chen, Y.L. \& Shin, Y.C.D. (2002): Study on the detection method of six varieties of genetically modified maize and processed foods. J. Food Drug. Anal., 10, 25-33.

CSN EN ISO 21569 (2005): Potraviny - Metody pro detekci geneticky modifikovaných organismů a odvozených produkti̊ - Metody založené na kvalitativním stanovení kyseliny nukleové. (Foodstuffs - Methods of analysis for the detection of genetically modified organisms and derived products - Qualitative nucleic acid based methods.) International Organisation for Standardisation, Geneva, pp. 1-84.

CSN EN ISO/IEC 17025 (2005): Posuzování shody-Všeobecné požadavky na způsobilost zkušebních a kalibračních laboratorí. (General requirements for the competence of testing and calibration laboratories.) International Organisation for Standardisation, Geneva, pp. 1-48.

Dinon, A.Z., Bosco, K.T. \& Arisi, A.C.M. (2010): Monitoring of Bt11 and Bt176 genetically modified maize in food sold commercially in Brazil from 2005 to 2007. J. Sci. Food Agr., 90, 1566-1569.

Elsanhoty, R.M., Al-Turki, A.L. \& Ramadan, M.F. (2013): Prevalence of genetically modified rice, maize, and soy in Saudi food products. Appl. Biochem. Biotech., 171, 883-899.

Fernandes, T.J.R., Amaral, J.S., Oliveira, M.B.P.P. \& Mafra, I. (2014): A survey on genetically modified maize in foods commercialised in Portugal. Food Control, 35, 338-344.

GeneScan (2007): GMO Ident Herculex I Corn manual, ver. 2.1 (1/2007), Germany

GMO Compass (2015): GM maize in the EU. Available at: http://www.gmo-compass.org (Last accessed September $15,2015)$

Herzallah, S.M. (2012): Detection of genetically modified material in feed and foodstuffs containing soy and maize in Jordan. J. Food Comp. Anal., 26, 169-172.

JAMES, C. (2014): Global status of commercialized Biotech/GM crops: 2014. ISAAA Brief No. 49. ISAAA: Ithaca, NY, USA. 24 pages.

Kiм, J.H., Zhang, D. \& Kiм H.Y. (2014): Detection of sixteen genetically modified maize events in processed foods using four event-specific pentaplex PCR systems. Food Control, 35, 345-353.

Kyrova, V., Ostry, V., Laichmannova, L. \& Ruprich, J. (2010): An occurrence of genetically modified foodstuffs on the Czech food market. Acta Alimentaria, 39, 387-396.

Mäde, D., Degner, C. \& Grohmann, L. (2006): Detection of genetically modified rice: A construct-specific real-time PCR method based on DNA-sequences from transgenic Bt rice. Eur. Food Res. Technol., 224, 271-278.

Mazzara, M., Foti, M., Maretti, M., Savini, C. \& Van den Eede, G. (2005): Report on the in-house validation of an event-specific detection method for event. Bt 10 using a qualitative PCR assay and verification by restriction analysis. $C R L$, JRC, Ispra, 15 pages.

Oguchi, T., Onishi, M., Mano, J., Akiyama, H., Teshima, R., Futo, S., Furui, S. \& Kitta, K. (2008): Development of multiplex PCR method for simultaneous detection of four events of genetically modified maize: DAS-591227, MIR604, MON863 and MON88017. Food Hyg. Safe. Sci., 51, 92-100.

Ozgen Arun, O., Yilmaz, F. \& Muratoglu, K. (2013): PCR detection of genetically modified maize and soy in mildly and highly processed foods. Food Control, 32, 525-531.

QAim, M. (2009): The economics of genetically modified crops. Ann. Rev. Resour. Econ., 1, 665-693.

Raven, P.H. (2014): GM crops, the environment and sustainable food production. Transgenic Res., 23, $915-921$.

Ronald, P. (2011): Plant genetics, sustainable agriculture and global food security. Genetics, 188, 11-20.

Turkec, A., LuCAS, S.J. \& KarLiK, E. (2016): Monitoring the prevalence of genetically modified maize in commercial animal feeds and food products in Turkey. J. Sci. Food Agr., 96, 3173-3179.

Ujhelyi, G., Vajda, B., Beki, E., Neszlenyi, K., Jakab, J., Janosi, A. \& Gelencser, E. (2008): Surveying the RR soy content of commercially available food products in Hungary. Food Control, 19, 967-973.

Zdjelar, G., Nikolic, Z., Vasiljevic, I., Bajic, B., Jovicic, D., Ignjatov, M. \& Milosevic, D. (2013): Detection of genetically modified soya, maize, and rice in vegetarian and healthy food products in Serbia. Czech J. Food Sci., 31, 43-48. 